\title{
Complaining Before and After 1984 Robert Wexelblatt
}

WE ALL KNOW COMPLAINING when we hear it. All the same, I think it proper and in the spirit of philosophy to begin with a little bit of definition; at least it will give me something to be inconsistent about later on.

In the vast and not completely charted realm of dissatisfaction, complaining is the intimate opposite of wishing. Intimate opposites, incidentally, are things like men and women: from the back you can sometimes mistake the one for the other. A wish means, at base: "I do not want to be as I am, to be what I am. And I shall relieve myself of this distasteful reality through delightful if wholly unrealizable fantasy." So, to wish is to deny what is real. Complaining, on the other hand, is apparently the very worst kind of acceptance of reality. Fundamentally, to complain is to say: "I am stuck where I am, as I am, and with the bad things that are happening to me. But I will seek a perverse and malicious relief in whining about it. Out loud." So, because one rejects and the other accepts reality, wishing and complaining are opposites; yet they are intimates because both agree that reality is decidedly unsatisfactory.

You might say that complaining is grown-up wishing or that wishing is what complaining regresses into. I mean this quite literally. An unhappy and imaginative fourth-grader is apt to do a good deal of wishing, but if he grows up to be a miserable certified public accountant, he will probably do a lot of complaining. Conversely, a large number of complaints wind up in wishes, though these are customarily negative and rather joyless ones. You may have noticed that after a good long bout of whining, people will express all sorts of merely vacant or rhetorical wishes, such as: "I wish I hadn't, didn't, needn't, wouldn't, or weren't." We can all furnish our own predicates.

Complaining is also, of course, the most popular competitive sport in the kingdom of the dissatisfied. Materialists will one-up each other with vacations and sports cars, intellectuals with book titles and obscure allusions, social climbers with dropped names and invitations - but the dissatisfied characteristically do it with complaints, as in "You think you had 
it bad? That's nothing. Just look at $m y$ scar!" In such a competition, the formulation of a really unanswerable complaint is as satisfying as spiking the ball in the end-zone.

Now, stoicism is invariably impressive and an uncomplaining temperament is always highly reputable. I might as well at once admit the obvious - that complaining has a poor reputation, though most of us do a great deal of it. Complaining is in this respect not unlike sneezing in public: I expect we have all been guilty of both sneezing and whining -in fact, there are times when even the most self-controlled of us simply cannot help doing so-but this does not prevent us from feeling little sympathy for those who do either in our vicinity. Complaining - there is no getting away from it - is an undignified topic. Dignified things, like ambassadors and grandfather clocks, always appear incapable of complaining, and the most dignified people at their most dignified moments are utterly beyond it: Marcus Brutus accepting defeat at Philippi, Spiro Agnew pleading no defense, Charlton Heston expiring on Mount Pisgah, and so forth. Why, then, look into such an unpromising matter?

First, I have spent an inordinate amount of time in schools, especially universities. While I cannot speak about such institutions as the Coast Guard or the World Bank, I have always been struck by the intensity and persistence of complaining at virtually every level of education. I spent a couple of years at Brandeis University, for instance, and my experiences there led me to suggest that the University's lengthy, hopeful and surgical motto ("Truth even unto its innermost parts") really ought to be amended simply to "It's not fair," as I heard the latter phrase so much more often than the former. In Latin it wouldn't sound so bad, actually: "Non aequus est," perhaps emblazoned on a shield with unbalanced scales.

Students complain as a matter of course; it is a mode of discourse natural to the condition of their transitional and perpetually graded lives: they are too old for childish wishing and too young for taciturn resignation. But professors are likewise very accomplished at complaining, and at every rank. There are, for instance, those who complain that they do not have tenure and those who, no doubt feeling trapped by security, complain that they do; those who complain that their students are as passive as oil paintings and those who complain that their pupils continually interrupt lectures with annoying questions. Hard though it may be to believe, even administrators have been know to moan on occasion - and in public. "If any 
man wishes to become humbled and mortified, let him become President of Harvard College," whined the eleventh President of Harvard College. For all I know about it, griping may be an ineluctable accompaniment to the educational process, like the figured bass in a concerto grosso. In any case, though, an examination of complaining does not seem out of order to me, since I work in a place that enjoys so much of it.

In fact, this idea of looking closely at complaining is only indirectly mine; it was actually. given to me by a 32-year-old woman named Virginia. She was and continues to be a character in a long story I wrote one summer. Not just a character, but the narrator.

Narrators can get hold of all sorts of strange ideas. They are wilful and notoriously difficult to control. Perhaps this is because they think they are authors. Anyway, at one point Virginia became attached to the idea of complaining and wouldn't let go. In the story, she is opening up an art gallery, her own business, and is in a perpetual tizzy about all the people she must cope with: her artists, her children, her stolidly uncomplaining husband, her carpenter, her accountant, etc. She is a spunky entrepreneur but nervously calls herself a "cowardly suburban Mother Courage." Like most modern narrators, of either gender, Ginny is pretty self-conscious, and the anguish of going into business makes her fully aware for the first time that complaining had always been one of her particular pleasures and greatest talents. Much to my surprise, though she did not at first strike me as having a philosophical bone in her imaginary body, Ginny insisted on pursuing this insight further. I begged her just to get on with the story, but she insisted: ". . . it would be letting myself off far too easily to make light of my complaining. What I want is to do just the opposite; I want to make heavy of it, like those philosophers I was compelled to read during my sophomore year."

I am unsure just where Virginia spent her sophomore year, incidentally, but since philosophers say the same things everywhere it scarcely matters. Anyway, here is some of what she had to say:

“. . . The whines of dogs and shudders of horses notwithstanding, I have come to believe that complaining is one of the truly distinctive human activities. At the very least, it's one that we have perfected. That is to say, we are complaining featherless bipeds. Just about our whole culture is a sort of complaining or, to put it a little more philosophically, complaining is our culture's efficient cause. The Bible fairly bursts with 
complaints (beginning with that business about the Garden of Eden and reaching a climax with Job); Prometheus Bound, the most primitive of Greek tragedies, is virtually nothing but whining; the sculpture of the Golden Age is an implied complaint (assuming Phidias himself was no mesomorph); music complains very gloriously, very lugubriously, depending on the major or minor; the history of politics is certainly founded on complaining; poetry is, at base, the quintessence of lyrical bellyaching. And so on.

"Like my kids, my artists are great complainers one and all . . . even when they have nothing to complain of except being themselves. And this is the real clue to the whole issue. The purest kind of complaining is never about anything external. That is only how it gets itself expressed: the teachers, the critics, the weather, the family, the car, or the economy must bear the brunt of all the interior displeasures. Voluptuous complaining, jagged complaining, lustrous complaining - through these we inflict our irritation at being ourselves on those who are not ourselves. 'Sorry to complain so much,' people will say with shocking hypocrisy. The apology itself is a complaint.

"In complaint as in art, every generation must produce its own stuff. In fact, we can judge a generation on the quality of its complaining as well as on the objects it picks to complain about. One generation complains that it can't make up its mind between Protestantism and Catholicism, another that you can't buy a good five-cent cigar, a third that social justice is irritatingly elusive. And, of course, they all complain about the last generation and the next one, in that order.

"Even the Stoics, as I dimly recall them, complained . . . they complained quite shamelessly about the complaining of the non-Stoics.

"As for happy people, they complain with surprising frequency because, being happy most of the time, it is simply impossible for them to bear in silence those rainy afternoons, those sleepless midnights when they areno matter how happy by nature - a little less than happy. Woe to the companion of the unhappy happy person!

"Men like to pretend that complaining is distinctively feminine; they have even reduced a myriad of the ills of our tangled innards to so many socalled 'women's complaints.' But, in my experience, men are the greater complainers. Not in quantity perhaps, but in quality, just as women do most of the world's cooking while the least over-worked, most famous, and best-paid chefs are men." 
Here I might say that I think Virginia's somewhat expansive idea of complaining is fundamentally an aesthetic one, and in this respect I quite agree with her. Some complaints, aesthetically speaking, really are better than others.

While the psychologists' concept of a "hierarchy of needs" has always seemed to me something of a misplaced metaphor, a "hierarchy of complaints" strikes me as just right. A hierarchy was originally a government of priests, which is what the Greek word literally means. Then Dionysius the Areopagite, who apparently knew everything worth knowing about the organizational chart of Paradise, used the term to designate the three ranks of angels, each rank having three orders for the sake of symmetry. But nowadays all that has been retained in common parlance of "hierarchy's" noble etymology is the Sesame Street notion that some things are above other things.

This is just where I object to the psychologists' hierarchy of needs: that is, the notion that when you've had enough peanut-butter-and-jelly you want to meet Mick Jagger and then, perhaps, read a little Harold Robbins. The third need is not necessarily higher than the second, let alone the first. In fact, some people may achieve their very highest point, their apogee of needful expression, at the level of biology. For example, a man may be the most exquisite Lucullian gourmet and yet be satisfied to listen to a recording of "Hey, Jude" by the 1001 Strings while polishing off his Sachertorte and smoking his Maria Mancini.

On the other hand, a hierarchy in the aesthetics of complaining seems to me very apt. Some complaints are truly nobler than others, more elevated and refined. The same person who will tell a whining child in a station wagon to shut up and stop complaining about the length of the journey may pay the very strictest attention to a performance of Mahler's Kindertotenlieder. Of course, we will not admit that it is the sheer elegance of imaginary complaint that attracts us to Mahler's music; we are more likely to say it is his passionate self-expression. Well, the whining child is expressing himself no less passionately when he moans for the twentieth time, "Are we there yet?"

Yes, you will say, but the child is only repeating the same irritating complaint. True, but then the poet Rückert wrote well over two hundred elegies on the death of his children, from which Mahler drew five for his songs. 
You will now object that Rückert was lamenting a most serious and irreplaceable loss, while the child in the station wagon is merely complaining about a trivial matter. Trivial to whom, I will have to ask in return. To us? But which of us really grieves for Mahler's musical empathy with Rückert's terrible loss? More likely we will think of some loss of our own or even a literary one. No, on the criterion of sheer sincerity, genuine, spontaneous feeling, we should have to place the child's automotive complaining higher than either Rückert's poems or Mahler's songs. After all, the child's whining is whole-hearted and unmediated by any secondary considerations, whereas Rückert forced himself to lament in rhyming couplets and Mahler in precisely weighed harmonies. If all the same we place Mahler's gorgeous grieving above the child's annoying whining, we might as well confess that it is because the one is beautiful and moving and the other ugly and exasperating.

We also cannot make the criterion of our hierarchy the degree of seriousness of the matter being complained about. It was Hazlitt who pointed out that tragedy and comedy are both complaints about the difference between the way things are and the way they ought to be. In tragedy the matter of complaint is serious, while in comedy it tends to be trivial. No doubt this is why, as forms, tragedy has generally enjoyed greater prestige than comedy. However, as soon as we look at particular cases - say, a solemn heroic tragedy by Otway and a Romantic comedy by Shakespeare-we must confess that there is a higher quality of complaining to be found in the comedy than in the tragedy. This is simply because Shakespeare's art is greater than Otway's - not merely his language, which by itself can make good literature, but not great literature. Actually, it is Shakespeare's profound artist's grasp of the human capacity to do things - things like complaining. Virginia would no doubt be quick to observe that Shakespeare's most famous play of all is largely devoted to complaining.

Virginia's idea about the huge element of complaining in western culture is not wholly frivolous. In fact, it reminded me of two anecdotes which I should like to offer here as exempla, as two types not only of the artist or thinker, but likewise as illustrations of two sorts of complaining, or even as two opposed orientations toward all those things about which life offers us the endless opportunity to complain. We might call them the ancient-heroic versus the modern-pathetic. 
The first story is apocryphal and concerns Alexander the Great. The tale is that when Alexander's conquest-weary and homesick veterans were near a decision to mutiny, having been on the march for over three years, he set himself high on a platform where the entire army would be able to see him, stripped off his robes and showed them that he bore on his own body the mark of every known weapon. He said not a word, nothing. The army pushed on towards the Gates of India, persuaded, I have always supposed, less by the pain Alexander had personally suffered than that, in disclosing his wounds, Alexander showed them a triumph more impressive than the sack of Persepolis. Like the Homeric heroes on whom he consciously modeled himself, Alexander was capable of complaining with enormous dignity - so much, in fact, that one might hardly notice it was complaining at all. In literature, such complaining is properly called tragedy, which is a sort of complaining through not complaining.

The second story concerns the German Renaissance artist Albrecht Dürer; it accounts for one of his more striking self-portraits. According to this anecdote, Dürer once fell ill during a journey. Distrusting the medical science of the rude village in which he found himself, the artist posted a circumstantial account of his symptoms to his personal physician back home in Nuremberg. To illustrate this description, he included along with his letter a small drawing: a full-length self-portrait in which the artist represented himself naked and pointing to the side of his abdomen. The caption reads, approximately, "This is where it hurts."

As I think about the form and style of modern complaining, I cannot help but feel that there is little which resembles the self-possessed, tragically dignified Alexander up on his platform and much that is like Dürer drawing out his complaint in a provincial sickroom for an absent Doctor. One might almost think that, among the many glossy new anthologies offered for sale each spring, at least one ought to be entitled, after Dürer: This Is Where It Hurts: An Introduction to Modern Literature.

The heroic and tragic complaint, like Alexander's, expresses the universal in the particular; the old Macedonian campaigners could identify themselves with their leader. To take another example, Achilles' personal complaint is still that of Achilles - a hero and demi-god-yet his heel is as mortal as our own poor flesh is. When in the Iliad he replies to a Trojan's appeal for mercy, Achilles speaks of himself, but explains that there is no mercy for any of us. His speech to Lycaon mirrors the stern pathos of Alexander's silent appeal to his troops: 
See what a man I am also, both strong and comely to look on, Great was the father who bred me, a goddess the mother who bore me;

Yet over me stand death and overmastering fortune.

To me a dawn shall come, or a noontide hour, or an evening, When some man shall deprive me of life in the heat of battle, Casting at me with a spear or an arrow shot from a bowstring.

It is as if Achilles understood the paradox that his invulnerability would be meaningless without his vulnerability. This is the sort of nobility taught us by the Greeks, the nobility Nietzsche shrilly complained the nineteenth century had destroyed with its endless moralizing and psychologizing, lowering the quality of complaining even as it vastly increased the quantity.

Fate is character. Anyway, this is what I was taught in high school. A nice dramatic-psychological idea, of course, illustrated as usual by the standard high-school reading of Oedipus Rex. And yet how much truer to the Greek tragic spirit I found Oedipus' own denial of my teacher's axiom when I later came across him complaining forcefully about it at the end of his life in Oedipus at Colonus:

Was I the sinner?

Repaying wrong for wrong - that was no sin,

Even were it wittingly done, as it was not.

I did not know the way I went. They knew:

They, who devised this trap for me, they knew.

Oedipus learns that his freedom can only be expressed in a context of necessity. This is a bitter, tragic wisdom, but a wonderfully ennobling one, too. In fact, when he finally accepts it, Oedipus becomes sacred, like the precincts of Moira, the terrain of Fate itself. But still, he complains. He blames them. If this demonstrates nothing else, it at least proves that at the end Oedipus is still man, still human, still the answer to the Sphinx's riddle. Man complains on four, then two, then three legs.

This ancient sublimation of the human spirit of complaining in epic or tragedy is bound to appear to us now like an expensive and even deceitful portrait. I mean the kind in which the photographer has contrived to 
make his wealthy client look almost hilariously better than in actuality, the sort of flattering photo the client wouldn't mind seeing in the newspaper or hanging on his children's walls. Nowadays, though, most complaining - even that offered by our public figures - is far more like the snapshots left over from last summer's torrid heat wave. After all, Alexander, Achilles, and Oedipus were heroes and kings. Facing life as they did, from the top, they all respected themselves.

It was Dostoevsky, inventor of the modern anti-hero, who asked rhetorically whether an educated, self-aware man of the modern world can really respect himself at all. Others have probed here and there, but no one, I believe, has poked his finger further into the soft psychology of modern, up-to-date complaining than Dostoevsky did. It is a psychology I have never felt secure enough to call abnormal.

Notes from Underground is a short novel in which, to adopt a phrase of Woody Allen's, Dostoevsky first succeeded in raising "whining to a high art." He does so not through heroic self-possession or tragic wisdom, but through raw, suppurating, and ignoble self-consciousness. In Chapter Four of Part One of the Notes, the anonymous narrator examines the spiteful pleasures of self-conscious complaint. The difference from the classic style is most striking. Listen to him improvise on his theme, like John Coltrane really letting go:

I ask you, gentlemen, listen sometimes to the moans of an educated man of the nineteenth century suffering from toothache, on the second or third day of the attack, when he is beginning to moan, not as he moaned on the first day; that is, not simply because he has a toothache, not just as any coarse peasant, but as a man affected by progress and European civilization. . . . His moans become nasty, disgustingly malignant, and go on for whole days and nights. And of course he knows himself that he is doing himself no sort of good with his moans; he knows better than any one that he is only lacerating and harassing himself and others for nothing; he knows that even the audience before whom he is making his efforts and his whole family, listen to him with loathing, do not put a kopek's worth of faith in him, and inwardly understand that he might moan differently, more simply, without trills and flourishes, and that he is only amusing himself like that from ill-humor, from malignancy. . . 
Imagine! Trills and flourishes, and all to say: here is where it hurts, to inflict this knowledge on others, on his "whole family." This is not expressing the universal in the particular, but just the opposite. That is, maybe everyone else gets toothaches, but just listen to what $m y$ toothache is doing to me. Egoistic complaining of this sort is malicious indeed. It is a sort of sin.

Kafka, in one of his penetrating late aphorisms, elevates the concept of complaining as sin to the highest conceivable level:

The original sin, the ancient wrong committed by man, consists in the complaint, which man makes and never ceases making, that a wrong has been done to him, that the original sin was once committed upon him.

Dissatisfaction, not with a toothache-that is merely a symbol-but with reality, with the conditions originally laid down for our existence - each man and woman with his or her own existence and all men and women collectively with existence in general - this becomes for Kafka the first sin, our fall from grace. (Could the unfallen complain?) Yet such complaining is also the serpent that leads us to bite the apple of knowledge: both complaining and biting are aggressive, oral acts.

Having once set out on this path of knowledge running east from Eden, our complaints have, moreover, dictated the program of our astonishing discoveries. Gravity, inertia, illness, aging - such conditions we have tried to overcome through our inventiveness: with our airplanes, drugs, and tummy-tucks. One might easily suppose Dostoevsky's Petersburg intellectual would fare better in the days of dental bonding and Novocain. But if the sin is really the original one, then this complaining must be both universal and perpetual, ineradicable even by scientific progress or Californian self-help healers.

Woody Allen's self-deprecating persona is at its best a burlesque of Dostoevsky's narrator. In effect, between the former's St. Petersburg and the latter's Manhattan there is no difference except a hundred years of human inventiveness and modern literature, which breeds the ironic and unavoidable knowledge of what is intractable to even a century of science and literature: 
Science has failed us. True, it has conquered many diseases, broken the genetic code and even placed a man on the moon, and yet when a man of eighty is left in a room with two eighteen-year-old cocktail waitresses nothing happens. Because the real problems never change.

What can we do about these real problems that never change? We can accept them in silence; we can complain about them as beautifully and even as gaily as possible, but there is something else we can also do: we can protest. We can protest because we must, because who knows whether the real problems that never change may turn out to be really changeable after all? We can also protest in order to remind others that the real problems are really problems.

We can assert our personal protests in the strongest terms. We have a long tradition of it. For example, in one of Kierkegaard's books an irritable young man writes of our whole vast business concern of a universe as follows:

How did I obtain an interest in this big enterprise they call reality? Is it not a voluntary concern? And if I am to be compelled to take part in it, where is the director? I should like to make a remark to him. Is there no director? Whither shall I turn with my complaint? Existence is surely a debate - may I beg that my view be taken into consideration?

Well, this is how intellectuals complain, and one should never underestimate the complaints of the intellectuals. Karl Marx, for instance, was for a long time troubled by a skin disorder and was not reluctant to complain about it. He is said to have remarked, while composing Das Kapital, "The capitalists will have cause to regret my carbuncles!"

Before we get carried away with the moral worthiness of complaining as protest, however, it should be admitted that complaining is also a thing many people do long before everything else has failed. This is plainly irritating, and here is an example. I have often to review the evaluations students make of my colleagues, the marketing reports on their pedagogy, so to speak. Not long ago I read a complaint recorded by a dissatisfied undergraduate: "Professor X. is far too demanding of and unsympathetic toward his students. It is useless to talk to him about the material when 
you haven't read any of it." It may be noted that complaining sometimes creates respect for that about which the complaint is lodged-especially when the complaint is manifestly premature.

Complaining can also be a sort of parasitic mood. Certain kinds of behavior are like viruses: they inject themselves into an organism and establish conditions in which they are able to reproduce like mad, the poor host be damned. I believe some people are afflicted with their complaining in just this viral way. In such cases, complaining would be as uncontrollable by the complainer as a fever is by its victim. At best, such a person might be able to channel his or her complaints; eliminating them is out of the question. One sees this sort of thing most clearly in young children, with whom a bad mood is always on the surface and with whom complaints multiply themselves rather indiscriminately: first they hate the meat loaf, then the milk, their clothes, bed-time, and their siblings. But at least children do not mask complaints as something else. In adults, this chronic viral complaining can take on many odd, protective colorations: for instance, pounding out the "Revolutionary Etude" or devoting long essays to the subject of complaining. Such grown-up activities are known as displacements or sublimations, suggesting that they are at least okay with psychologists. Give your whining an air of high culture, put it down in octava rima or daub it in bold acrylics and people won't be so annoyed with you. On the contrary, a few of them may even invite you to dinner.

But meanwhile, the viral devil of complaining - the passive dissatisfaction, the profound dis-ease-goes on eating away at the organism which now calls itself artistic and arrogates to itself as many privileges as that dignified claim will win. In this way, complaining can even become quite necessary to the artist - not surprisingly, as he will, not without some justice, begin to call it inspiration. Nor is this process of sublimated complaining limited to poets or musicians.

Some lawyers are very good at it: talented ones soon become masters of reflexive courtroom objection and the very best are capable of inventing entirely new kinds of civil litigation. The difference between mere whining litigiousness and a genuine thirst for justice may be absolute; however, as this distinction is a wholly interior one, it is very difficult from the outside to tell which is which. This must be why our courts are congenitally clogged with complaints. Indeed, the large if not excessive number of lawyers employed in the United States suggests that formal complaining 
is, for Americans, not only a way of doing business but virtually a national pastime. After all, as I recall, one of the major sources of the American national consciousness was a series of famous complaints about British economic and defense policy in the eighteenth century. The American Revolution was, in many ways, a revolution made by lawyers. This proves nothing against the sources of American patriotism, Heaven knows, but it does reveal that the spirit of complaint can lead to highly consequential and liberating actions. An irritation can suggest a new train of thought, new thoughts can beget protests, and protests may lead to insurrections. This was clearly understood in the old feudal days when, if somebody complained about the King, he could be brought up on a charge of lèse-majesté and dealt with as a traitor.

My point here is that free thought is unimaginable without complaining, though complaining is no more a sign of independent thinking than tuberculosis is of literary genius. It's just that, historically, the two have often been found together.

So, to complain has a legal meaning as well as a psychological one. To lay a complaint before a court is to assert that an injustice exists and to seek its redress. In this sense, George Orwell's cautionary novel 1984 is a very complicated complaint, meticulous and imaginative, an extrapolation from an unacceptable present to an entirely repulsive future. The connection between the present and future is not only real, it is sometimes quite personal. Orwell gave the number of the room in which he labored during the war to the dreaded torture chamber in which Winston Smith confronts the rat. But, of course, the novel is hardly personal; it is a protest, a legal complaint seeking an injunction, a restraining order, asking nothing less than justice and sanity for the world-at-large.

In fact, Orwell's whole career was that of a profoundly protestant writer. He was a man who complained constantly not that an injustice had been done to him, but rather that human decency was being multifariously outraged in his time.

When I first read 1984 as a boy the fact about it which most impressed me was that Winston Smith, the novel's protagonist, was born in the same year as myself. Now we are both forty. I am, of course, infinitely better off than Winston Smith. So far as I am aware, I do not even share his varicose ulcer, the wound of his oppressed individuality; that is, the physiological manifestation of many repressed complaints and stifled pro- 
tests. But I cannot wholly escape the idea that Orwell's book was meant in some special way for my own generation, for all of us once whining and protesting, but lately more accommodating baby-boomers.

I have therefore endeavored to remain mindful of his complaints and warnings about such things as the betrayals of which intellectuals are fully and perpetually capable, that utopian schemes generally tend toward controlled insanity, that indoctrination is ever ready to substitute itself for education (noting especially that in Orwell's Oceania only those who have no intellect are granted intellectual liberty), that the abolition of privacy spells the annihilation of the individual, and that a science dominated by government is likely to be reduced to examining only two questions: how to read the minds of human beings and how to kill large numbers of them without warning.

But none of these protests - serious and ever-timely as they are - constitutes Orwell's special complaint, the uniquely Orwellian gripe. Others have seen these things too, but absolutely no one has seen more clearly or complained more eloquently about the pernicious political and moral effects of the perversion of language. No one argues so lucidly or less school-marmishly that the degeneration of language is, in fact, equally a cause and an effect of cultural and political corruption. For example, Orwell observed that the weakening of language encourages us to accept words without examining their relation to objective reality. Our thought is impoverished and the truth obscured by clangorous slogans and reiterated nonsense. Orwell's historical sources for such political concerns are obvious enough: there are Stalin's grand dictates on the collectivization of Soviet agriculture, Mussolini up on his balcony fulminating about the grandeur of Imperial Rome, or Hitler screeching about the future of the Fatherland.

For my generation, however, these dictatorial linguistic grotesqueries were at first only of historical interest. At most, they appeared to us trivialized in the comparatively crude advertising of the 1950s. However, in the mid-1960s, just as we came of age, the debasement of political discourse about which Orwell complained suddenly appeared before us in all its ignoble obfuscatory panoply and has yet to go away.

There was something called the Pacification Program in Viet Nam, for example. To pacify means to make peaceful, as when a screaming baby is given a rubber nipple to suck on. "War is Peace," says Oceania's Inner 
Party. Why not reverse it? Pacification was, of course, war. People were removed from villages of questionable loyalty to crowded camps, the villages burned, along with crops and domestic animals. As a Roman once said of a similar program: "They make a desolation and call it peace."

There was something called the Phoenix Program, which seemed to entail the systematic assassination of civilians suspected of communist sympathies and not the rebirth of some fabled fire-bird in Arizona.

Notice also that these things were called "programs." Programs sound rather good in themselves. A program suggests a well-organized thing, something to watch on television or to feed neatly into your clean mainframe. It is a useful word.

At certain moments the war became almost literally a war of words. For instance, I recall that the Nixon Administration became rather indignant with journalists who insisted on referring to the invasions of Laos and Cambodia in 1970 as invasions. These were merely "incursions" the Administration declared warmly. Evidently they felt an incursion would be more appealing to the electorate than an invasion, and perhaps they were right. All the same, anyone with a dictionary could have discovered that incursion and invasion are essentially synonymous. The point is that the word is softer and implies something minor and brief, a headache rather than cancer. Throughout the war the official language-game seemed to be to find soft words for hard ones, abstract words for concrete ones, palliative jargon in which to swathe embarrassing facts. And all this occurred at just the moment when television journalism gave the lie to the Pentagon's lexicon of softness, abstraction, and palliation.

Yet television itself, with its battering montage, its vast emptiness full of images, can stupefy no less effectively than Newspeak can. It is this that leads me to complain now and again that one true word would be worth a thousand pictures. Winston Smith, a kind of historian after all, might have felt the same way. He was not a photographer, but a diarist.

Anyway, the specific linguistic perversions Orwell complains about are by now fairly common - though fortunately there are still plenty of people around to complain about them. For instance, in Newspeak, as in the Pentagon, nouns become verbs and vice-versa. In Newspeak there is no longer the word "thought." Its place is taken by "think," as "cut" is by "knife." Already we are practically surrounded by think-tanks and politicians famous for knifing through their own red tape. Orwell predicted that the 
"ly" ending of adverbs is doomed to be replaced. Madison Avenue became notorious for this two decades ago and the suffix "wise"-if I remember rightly - turns up now and then on the Nixon tapes, which is not surprising, since he surrounded himself with advertising men like Haldeman. "Will that story go over well public-relations-wise?" they ask, while over at the Pentagon they were perhaps inquiring, "How's that new bomb, kill-wise?"

It isn't just the government, of course. Students fall into error a good deal, too. For instance, Orwell is very sharp on "un" constructions, as in unfree and ungood. I have often heard students falsely describing absolutely genuine events as "unreal" or things they entirely credit as "unbelievable." This sort of thing ought to be quite unacceptable.

Orwell complains also of the characteristic Newspeak device of making new compound words - thoughtcrime, goodsex, oldthink, blackwhite. Time magazine used to make a specialty of this, inventing cute neologisms like "cinemactress." Agitprop, Gestapo, Comintern, and Nazi are older examples, compound abbreviations which had the original advantage of cutting out undesirable associations. Some years back, Standard Oil Company of New Jersey, which used to go by the Orwellian name of Esso, spent a terrific sum of money to change its name to Exxon and then ran ads selling itself as our buddy, ally, and servant-rather like Big Brother, in fact. Should people have complained that they were selling themselves and not just gasoline?

The distorted languages of business and of politics intersect in the advertising agency, which often aims at the same kind of compliant unconsciousness as the Inner Party favored in its clients. After all, a campaign is a campaign and every election brings us more media-consultants. Whether the purpose is more sales or more votes, the methods are pretty much the same: lulling the mind, defusing the sense of reality, invoking authority, bandwagons, nostalgia, and the religion of technology. Consider just the last: nobody uses a razor anymore. We use "shaving systems" like the TRAC-2 shaving system in which, of course, Trac is spelled incorrectly. You'd think that this fourth-generation chromiumplated stainless-steel double-edged teflon-enhanced quasi-scientific marvel was too good for merely scraping whiskers or for anything less than slitting your throat in high style.

Like Winston Smith's, our telescreens, albeit still one-way for the mo- 
ment, are full of Newspeak too. Take Orwell's device of the standardized adjective. In Newspeak, he says, there will be precious few of them because this will greatly lessen the chance of a fresh or accurate view of reality. The Inner Party favors stereotyping in particular and muddy thinking in general - or mudthinkfulness - which is greatly furthered by constantly using the same words. The press seems unable to report on a legal brief without putting the word "lengthy" in front of it. Except in underwear ads, there are no brief briefs on television. In the same way, the House Ways and Means Committee is regularly "powerful" while the Rules Committee is always "all-important." Truces in the Middle East are perpetually "uneasy," perhaps because the place is crowded with sheikdoms that are all "oil-rich," and enduring visits from "globe-trotting" secretaries-of-state who are fleeing "spiralling" inflation (or another "short-term" recession) back home, so that they can "officially" protest "alleged repressive" measures "necessitated" by the activities of "leftwing" guerillas who are "communist-backed" by threatening retaliation that promises to be "massive."

By all means let us complain with Orwell about such leaden and deadening clichés. It should not be that the very thing most citizens do to become informed about the world should prevent them from thinking clearly about what is going on. Let the machines be the receivers, not the watchers. And let us be grateful to George Orwell for his complaining no less than for his love of the English language.

So we have made it through both 1984s, still complaining, still free to complain, at least if we live in the right countries. Back in the 60s - when my generation told itself not to trust anyone over thirty-our complaints were memorable when of high quality; petulant, callow, and selfrighteous when otherwise. But the habit of griping is hard to break. So now, when we have told ourselves not to trust anyone under thirty, my coevals are complaining still, though the relative complacency of the present rather tends toward the trivialization and narrowing of complaint. Interest rates get more play than social justice these days. In fact, instead of outraged idealism, I hear more outrage at idealism. This new hard-headed, bottom-line (or middle-aged) appraisal of life by the baby-boomers casts a curious shadow over the next generation, many of whom are, so to speak, uncertain of just what to complain about for the rest of the century. Their 
attitude toward those of us who were their age in the $60 \mathrm{~s}$ remains profoundly ambivalent: on the one hand, I think they envy us our youthful and innocent certainty about our objects of protest, while, on the other, they are quick to see selfishness underlying the apparently indignant altruism of twenty years ago. They also envy our nostalgia, but rightly suspect it is often mere sentimentality and even a way of beating them over the head with the Beatles, Janis Joplin, and Dr. Spock. They wonder at the old far-reaching radicalism, but are quick to observe with a smile that such daring didn't so much fail as it was outlived, as if it were just like any other fad. They marvel at the freedom of the 60 s, at the motley variety of lives they spawned, but also understand that the 60 s were years of rising economic expectations which could underwrite a kind of luxurious silliness. They themselves do not seem to desire such a wide variety of styles in living, but rather something very particular, something along the lines of what life is like on Dynasty, Dallas, or other country-club soap operas. True, these young are modest; they do not tend to formulate grand, far-seeing complaints, apart from a rather hopeless feeling about nuclear annihilation when the thought strikes them-but they are not short on immediate ones: work loads, the weather, criticism. Non aequus est. It is not that they are uncritical or inarticulate about the Big Questions, but rather, I think, that they are plainly fearful, and fear makes for silence. Paradoxically, a degree of confidence and security is required to complain well. Complaining, like hope, depends on faith in the future. The more protected the child - the more pampered, assured, and the less afraid - the more it is liable to whine. To be blunt, I think the young who are middle-class are afraid of falling out of it, afraid that the system which offers such enormous material rewards may withhold its benefits or might even crush them should they make the wrong move. Given this, it is natural that they should mistrust or nervously mock complaining in the grand style. Moreover, one does not protest a system in which one is striving to triumph.

Even after all this, though, I must admit that complaining may be almost pointless, but in this narrow "almost" there remains much to consider. There is in it room not only for whining, breast-beating, the cruder forms of brattish self-assertion; there is also lodging for a proof of life, for sensitivity to irritation, space for the hope that things might be better than they are. I can only think of three sorts of people who do not complain in 
some way: the smugly complacent, the totally repressed, and the utterly despairing. My great respect for the silence of the Stoics and my detestation of the whining of the well-off notwithstanding, I cannot consider any of these conditions desirable.

Of course spoiled people do complain - in fact, they do little else-but not all complainants are spoiled. Besides, there is a purely social element in complaining which should not be overlooked. I believe many close friendships are owing to it. People who go through the truly complaint-worthy ordeals of life together (such as military training or their freshman years) tend to remain remarkably close, for they share the ineffable bond of having griped in common. This discourse called griping ought not to be undervalued as a precious lubricant in slipping us through abrasive times. Indeed, I think many complaints are really only a form of etiquette. One is not expected to like one's drill sergeant, freshman composition class, institutional food, rush-hour traffic, or crowded trolleys. Complaining, like shaking hands, gives one something comforting to do with strangers in barracks, cafeterias, classrooms and subways.

Complaining will cut us off from others if we only bewail our private fates; but it can connect us with others if we join ourselves to the human condition by it. There is a fine illustration of just these alternatives in the Talmud, an anecdote about the saintly rabbi Hanina ben Dosa, whose complaining prayers were evidently always answered instantly. Here is the whole story:

Rabbi Hanina was once walking along when it began to rain. At once he complained to God: "Lord of the World, all the world is at ease, only Hanina is in distress."

At once the rain stopped.

But when the rabbi reached his house he complained again. "Lord of the World, all the world is in distress, only Hanina is at ease."

And the rain started to fall once again.

Hanina's second complaint is the noble one. In the end, he did not pray that he should be better off, but that he should be no better off than others; not that he should rise above, but that he should share in the common fate; essentially that it should rain on the just as well as the unjust. The second complaint joins him to mankind and, in doing so, cancels the first.

One need not be a prophet to predict that people will go on complain- 
ing: no matter how glittering the future turns out to be, it will certainly displease somebody. Besides, as Virginia said, complaining is a fundamental human talent and, as such, necessary and not to be despised. We should develop all our talents. According to Kafka, we humans never cease to complain of the original sin, especially when we are in the process of committing it. And so people will undoubtedly go on complaining no matter what. But we can still choose our objects; we can still perfect our style. If art is complaint, then complaint can be art. So, to conclude, here are two final examples of really first-class complaining. They may stand as models. The first is one of Heinrich von Kleist's anecdotes:

A Franciscan, one very rainy day, was accompanying a Swabian prisoner to the gallows. The man complained to Heaven all the way of having to walk so gloomy a path in such wet and unfriendly weather. The Franciscan, wishing to offer some Christian solace, replied: 'Lout that you are! How can you complain? You have only to get there, but I, in all this rain, must walk all the way back again.'

The last is a most elegant and superbly polite complaint which is attributed to no less a personage than Abraham Lincoln:

Madam, if this is coffee, please bring me some tea; but if this is tea, please bring me some coffee. 